desks of serious scholars of the Chinese rites controversy and the clash of values that troubled the Jesuit mission surrounding the imperial court of Kangxi.

Anthony E. Clark

Whitworth University, Spokane, WA, USA

aclark@whitworth.edu

DOI:10.1163/22141332-00704008-10

\title{
Adam Parr
}

The Mandate of Heaven: Strategy, Revolution, and the First European Translation of Sunzi's Art of War (1772). Jesuit Studies 26. Leiden: Brill, 2019. Pp. xii + 323. €130.00 / $\$ 157.00$.

In The Mandate of Heaven, Adam Parr sheds light on the work of the Jesuit missionary and scholar Jean-Joseph-Marie Amiot (1718-93), particularly his Art militaire des Chinois, the first French translation of Sunzi's Art of War. Parr's impressive volume comprises a few distinct elements. It includes translations of the French text of the Art militaire into English that Parr put together with Dr. Gillian Pink, interpretive essays by Parr, a transcription of a letter written by Amiot to the French minister Henri Léonard Jean-Baptiste Bertin (1721-92), and a biographical essay on Amiot written originally in French by historian Michel Hermans, S.J. and translated into English by Dr. Alison Oliver. Together, these elements reveal the contributions that Amiot made to the intellectual and political worlds of the eighteenth century. The translation of Amiot's text, which functions as chapters two and three in the book, is clear and informative. The biography of Amiot includes useful background information on Amiot's life, education, and work in China. This review, however, will focus on Parr's explanatory essays included in the introduction, chapters 1 and 4, and the postscript.

Parr's main objective is to explain why Amiot wrote his translation when he did and what the larger impact of the work was, particularly within the setting of eighteenth-century France. Parr argues that to understand what Amiot was trying to accomplish in translating the Art of War one must place it within the culture of the Enlightenment and the French Society of Jesus. More specifically, Parr claims that Amiot "interacted with and influenced" the French Military Enlightenment in important ways (7). Amiot's presentation of Chinese military strategies supported the notion that warfare was a science consisting of "constant and universal laws" that applied to all contexts and situations (172). Parr also ties the Art militaire to the formulation of the then nascent 
concept of modern military "strategy" (216). Similarly, Parr shows that Amiot's text must be understood within the larger contexts of Jesuit missionary culture and the tumultuous historical moment of the 1760 s. He attributes the genesis of the book to the expulsion of the Jesuits from France and the threat that the expulsion placed on the China mission of which Amiot was a leading member. Jesuit missionary culture also explains the ways in which Amiot went about translating the Art of War. Amiot cross-referenced different versions of the manuscript in both Chinese and Manchu, an act that reflected the Jesuits' deep commitment to linguistic study. He provided a "loose translation" to accommodate the eventual reader of the Art militaire instead of maintaining the precision of the original language - a scholarly decision reminiscent of the wider culture of "accommodation" employed by Jesuit missionaries throughout the early modern world (51). His handling of complex concepts such as the dao (道) and ren (仁) displayed Amiot's commitment to the Jesuit reading of Chinese culture as widely compatible with Christianity. In brief, Parr shows that the Art militaire was both a piece of enlightened scholarship and a promotional document for the Jesuit missionary worldview.

Parr's boldest claim, however, is that Amiot's Art militaire provocatively promoted the "concept of legitimate revolution" in the decade preceding the most significant revolution in French history (195). To make this case, Parr sets Amiot's text within the general movement of Sinophilia developing in eighteenth-century France. For many Enlightenment-era writers, China provided a useful tool with which to level indirect critiques at the French monarchy. In his description of the overthrow of the Ming dynasty in 1644, Amiot legitimizes the acts of the conquering Qing and repeats their narratives about how the Ming had lost the "mandate of heaven." When Amiot's Art militaire arrived in France, it joined a collection of other texts-many of which were written by the Physiocrats - that used the subject of Chinese politics and culture to promote radical economic and political action. Parr's connection of the Art militaire to calls for revolution is, by his own admission, a "radical reading" of Amiot and his influence, but it is well-articulated and, in some ways, reflects a vision of the Jesuits' sometimes antagonistic relationship with early modern states promoted most vociferously by the Society's eighteenth-century critics (195).

Parr impressively contextualizes Amiot's significant literary production and makes a compelling case for its broader impact on the intellectual and political worlds of eighteenth-century France. His explorations of Amiot's scholarly world and the connections between Jesuit missionaries and French royal ministers, particularly Bertin, are invaluable for scholars of the early modern Society of Jesus. Indeed, he uncovers a fascinating collection of letters 
between Bertin and various Jesuit missionaries in China currently held at the Bibliothèque de l'Institut de France in Paris that is well worth further study. Where his explanatory chapters might have done more is in drawing out the depth of the Military Enlightenment and its significance for Amiot's work. Parr relies on a three-part definition of the Military Enlightenment advanced by Armstrong Starkey that, while clarifying, is somewhat limiting $\left(5^{-6,165)}\right.$. It focuses on the writings of military theorists, but the Military Enlightenment in France included many more. Christy Pichichero's The Military Enlightenment: War and Culture in the French Empire from Louis XIV to Napoleon (Ithaca, NY: Cornell University Press, 2017), a book that Parr unfortunately overlooks, notes that the Military Enlightenment included many non-military writers from artists and royal bureaucrats to members of the broader public. Indeed, this broader definition of the Military Enlightenment might have worked to Parr's favor because his promotion of Amiot as a participant in the Military Enlightenment suggests that even missionaries contributed substantially to the larger goals of this intellectual movement. Pichichero's focus on the importance of "sentiment" and sensibilité in the writings of the Military Enlightenment also tracks well with Amiot and the ways that he framed Chinese military culture. A broader vision of the Military Enlightenment would have added further support to Parr's already convincing argument about the place and importance of Amiot's Art militaire.

The Mandate of Heaven is a welcome addition to studies on French Jesuits and their impact on the Enlightenment. Parr and the other contributors to the volume are to be applauded for their contributions to understanding eighteenth-century Jesuit missionary culture and the global connections that facilitated and inspired the Enlightenment.

\section{Daniel J. Watkins}

Baylor University, Waco, TX, UsA

Daniel_Watkins@Baylor.edu

DOI:10.1163/22141332-00704008-11

\section{Paula Findlen, ed.}

Empires of Knowledge: Scientific Networks in the Early Modern World. New York: Routledge, 2019. Pp. xvii + 394. Hb, \$175.00; Pb, \$42.95.

As historians of early modern Europe began to focus more on the global effects that resulted from exploration and empire, intellectual and cultural historians have followed suit. To what extent did knowledge and culture travel along 